\title{
THE IMPORTANCE OF SERUM ALBUMIN AND METABOLIC INTERMEDIATES FOR CAPACITATION OF SPERMATOZOA AND FERTILIZATION OF MOUSE EGGS IN VITRO
}

\author{
H. MIYAMOTO AND M. C. CHANG \\ Worcester Foundation for Experimental Biology, \\ Shrewesbury, Massachusetts 01545, U.S.A.
}

(Received 22nd December 1971)

\begin{abstract}
Summary. The acrosome reaction of epididymal spermatozoa and fertilization in vitro of mouse eggs in chemically defined media without tissue fluid were investigated. About 8 to $10 \%$ of motile spermatozoa lost their acrosome but no eggs were penetrated when the spermatozoa and eggs were incubated in a basic medium (modified Krebs-Ringer bicarbonate solution containing glucose) for 5 to $7 \mathrm{hr}$. Addition of a single metabolic intermediate, such as sodium oxaloacetate or sodium pyruvate, to the basic medium increased the proportion of motile spermatozoa without an acrosome (19 to $34 \%$ ) and the proportion of eggs penetrated (3.2 to $25.5 \%$ ). Incubation of spermatozoa and eggs in the basic medium containing serum albumin of various species caused a further increase in the proportion of motile spermatozoa without an acrosome (50 to $65 \%$ ) and in that of penetrated eggs $(60.7$ to $86 \%)$. The best medium for sperm capacitation and fertilization of mouse eggs in vitro, however, was the basic medium containing bovine serum albumin, sodium lactate and sodium pyruvate. The time required for sperm capacitation was $1 \mathrm{hr}$ in this medium, and $2 \mathrm{hr}$ in the medium containing only serum albumin. Certain components present in the oviducal fluid and in the cumulus egg clots, probably similar to serum albumin and sodium lactate or sodium pyruvate, appeared to be beneficial for the capacitation of spermatozoa and fertilization of eggs. It was concluded that serum albumin, sodium lactate and sodium pyruvate can be sub- . stituted for tissue fluid in the induction of capacitation of spermatozoa and fertilization of mouse eggs in vitro.
\end{abstract}

\section{INTRODUCTION}

The capacitation of spermatozoa and fertilization of hamster eggs in vitro can be effectively achieved in the presence of hamster follicular fluid (Barros \& Austin, 1967) or bovine follicular fluid (Yanagimachi, 1969a). In view of the similarities between follicular fluid and blood serum (Lutwak-Mann, 1954; 
Caravaglios \& Cilotti, 1957), it might be assumed that the latter would also be able to induce sperm capacitation. After the removal of a spermicidal factor present in blood serum by heating the serum (Chang, 1947), it was found that various sera were able to induce an acrosome reaction (Barros \& Garavagno, 1970) and capacitation (Yanagimachi, 1970) in hamster spermatozoa. Yanagimachi stated further that 'efficient sperm capacitation was induced in media containing both dialysable and albumin fractions of the sera. When one of these two fractions was absent from the medium, no capacitation or only very inefficient capacitation was induced.'

The capacitation of spermatozoa and fertilization of mouse eggs in the presence of heated bovine follicular fluid have been reported (Iwamatsu \& Chang, 1969, 1970, 1971). Recently, fertilization of hamster eggs (Bavister, 1969) and mouse eggs in vitro (Toyoda, Yokoyama \& Hosi, 1971) in media containing crystalline serum albumin and sodium pyruvate has been described. From the report by Bavister (1969), it appears that components of the cumulus egg clot may not be essential for the fertilization of hamster eggs in vitro, but Bavister's medium contains crystalline albumin and sodium pyruvate which may have the function of inducing sperm capacitation. The present study was designed to determine the importance of serum albumin from various species, some metabolic intermediates (dialysable substances), and substances present in the cumulus egg clot, for the capacitation of mouse spermatozoa and fertilization of eggs in vitro in chemically defined media.

\section{MATERIALS AND METHODS}

\section{Preparation of media}

The basic medium was a modified Krebs-Ringer bicarbonate solution, similar to the medium used by Brinster (1965) for the culture of mouse eggs. It contained $119.37 \mathrm{~mm}-\mathrm{NaCl}, 4.78 \mathrm{~mm}-\mathrm{KCl}, 1.71 \mathrm{~mm}^{-\mathrm{CaCl}_{2}}, 1.19 \mathrm{~mm}-$ $\mathrm{KH}_{2} \mathrm{PO}_{4}, 1.19 \mathrm{~mm}-\mathrm{MgSO}_{4} .7 \mathrm{H}_{2} \mathrm{O}, 25.07 \mathrm{~mm}_{-} \mathrm{NaHCO}_{3}, 5.56 \mathrm{~mm}$-glucose, $50 \mu \mathrm{g}$ streptomycin sulphate $/ \mathrm{ml}$ and $75 \mu \mathrm{g}$ penicillin $\mathrm{G}$ (potassium salt) $/ \mathrm{ml}$. Various concentrations of bovine (crystalline), horse (Powder, Fraction V), rabbit (crystalline) or human (Powder, Fraction V) serum albumin (Sigma Chemical Company) and some metabolic intermediates, such as sodium lactate or sodium pyruvate were added just before use for each test. By addition of $1 \mathrm{~N}-\mathrm{NaOH}$ or $\mathrm{HCl}$, the $\mathrm{pH}$ value of each medium was adjusted to 7.4 to 7.5 and the final solution was sterilized by filtering through a Millipore filter.

\section{Preparation of sperm suspension for the assessment of acrosome reaction}

Sperm suspension was prepared by mincing the caudae of the epididymides of a mature Swiss Albino mouse in a watch glass containing $2 \mathrm{ml}$ of a test medium. A few minutes later, a portion of the sperm suspension with very actively motile spermatozoa was drawn into a fine glass pipette and about $0.1 \mathrm{ml}$ of the suspension was added to $0.4 \mathrm{ml}$ of the same test medium in a watch glass containing the cumulus egg clot. The mixture was covered with paraffin oil (equilibrated with $5 \% \mathrm{CO}_{2}$ in air in the presence of a small volume of saline). The final concentration of spermatozoa in the suspension was 300 
to 2000 spermatozoa $/ \mathrm{mm}^{3}$. The preparations were incubated at $37^{\circ} \mathrm{C}$ in an atmosphere of $5 \% \mathrm{CO}_{2}$ in air. At various times after incubation, a small drop of sperm suspension was withdrawn and examined under a phase-contrast microscope. The numbers of motile spermatozoa and of those motile spermatozoa without an acrosome were counted at room temperature. Usually about 100 spermatozoa were examined in each sample and the proportions of motile spermatozoa and of motile spermatozoa without an acrosome were calculated.

Recovery of eggs for the study of fertilization in vitro

Mature female Swiss albino mice weighing from 21 to $26 \mathrm{~g}$ were injected intraperitoneally with 5 i.u. PMSG, followed by 5 i.u. HCG 44 to $48 \mathrm{hr}$ later. They were killed 14 to $16 \mathrm{hr}$ after HCG injection and their oviducts were placed into paraffin oil in a watch glass kept on a warm stage. The dilated portion of the ampulla was cut open and the cumulus oophorus containing eggs with a small amount of oviducal fluid was released into the oil. Then $0 \cdot 1 \mathrm{ml}$ of a suspension of epididymal spermatozoa in a particular test medium was added to the cumulus egg clot and about $0.4 \mathrm{ml}$ of the same test medium was added. The eggs and spermatozoa were thoroughly mixed with a glass needle and incubated.

In some cases, the cumulus mass containing eggs was washed three times in $1 \mathrm{ml}$ of a test medium in order to remove the oviducal fluid before the addition of sperm suspension. The preparation was covered throughout the experiment with paraffin oil and the final concentration of spermatozoa in each watch glass was as before. After incubation, which usually lasted for $5 \mathrm{ho} 7 \mathrm{hr}$, the eggs were washed with saline and mounted on a slide. They were then examined and fixed in $10 \%$ neutral formalin for $24 \mathrm{hr}$ and stained with $0.5 \%$ lacmoid in $45 \%$ acetic acid for further inspection.

In the presentation of results, 'penetrated eggs' denotes those eggs with spermatozoa in the perivitelline space and those undergoing fertilization. 'Eggs undergoing fertilization' denotes those eggs which had enlarged sperm heads and those which had pronuclei in the vitellus. 'Supplementary spermatozoa' denotes those spermatozoa in the perivitelline space that did not participate in fertilization. Polyspermy was assessed by the number of enlarged sperm heads or the number of male pronuclei in the vitellus with corresponding sperm tails.

\section{RESULTS}

\section{Acrosome reaction}

For the assessment of acrosome reaction, the proportions of motile spermatozoa that had lost their acrosomes at various times after incubation were recorded. From the results presented in Table 1, it can be seen that $5 \mathrm{hr}$ after the incubation of mouse epididymal spermatozoa suspended in the basic medium alone, $30 \%$ of the spermatozoa were motile and $9 \%$ of the motile spermatozoa were without an acrosome. The percentages of motile spermatozoa (48 to $63 \%$ ) and of motile spermatozoa without an acrosome (19 to $34 \%$ ) increased slightly when sodium oxaloacetate, trisodium phosphoenolpyruvate, sodium 


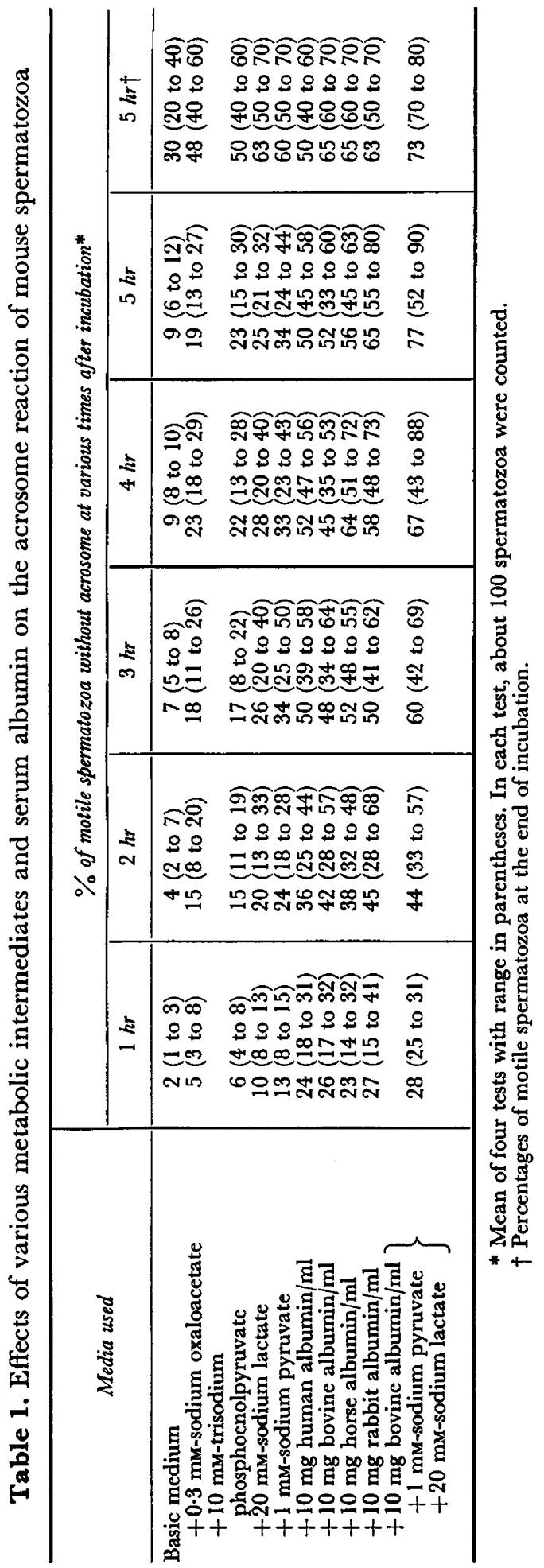


lactate, or sodium pyruvate was added to the basic medium. Addition of rabbit, bovine, horse or human serum albumin to the basic medium did not increase the percentages of motile spermatozoa ( 50 to $65 \%$ ), but markedly increased the percentages of motile spermatozoa without an acrosome (50 to $65 \%$ ). There was no significant difference between various serum albumins in induction of the acrosome reaction. The most effective medium to induce this reaction was that containing bovine serum albumin, sodium pyruvate and sodium lactate; here, the percentages of motile spermatozoa $(73 \%)$ and of motile spermatozoa without an acrosome $(77 \%)$ were the highest following incubation.

Effect of metabolic intermediates and serum albumin of different species on fertilization of mouse eggs in vitro

Various concentrations of metabolic intermediates were added to the basic medium for sperm capacitation and fertilization of mouse eggs in vitro. The results presented in Table 2 show that fertilization of mouse eggs cannot be

Table 2. Effect of metabolic intermediates on fertilization of mouse eggs in vitro

\begin{tabular}{|c|c|c|c|c|c|c|}
\hline \multirow[b]{2}{*}{ Media used } & \multirow{2}{*}{$\begin{array}{c}\text { Concentration } \\
\text { of substrate } \\
\text { (mM) in basic } \\
\text { medium }\end{array}$} & \multirow{2}{*}{$\begin{array}{l}\text { No. of } \\
\text { eggs } \\
\text { examined }\end{array}$} & \multirow{2}{*}{$\begin{array}{c}\text { No. of } \\
\text { penetrated } \\
\text { eggs }(\%)\end{array}$} & \multicolumn{3}{|c|}{$\begin{array}{c}\text { No. of eggs } \\
\text { undergoing fertilization }\end{array}$} \\
\hline & & & & $\begin{array}{l}\text { Total } \\
(\%)\end{array}$ & $\begin{array}{l}\text { Mono- } \\
\text { spermic }\end{array}$ & $\begin{array}{l}\text { Poly- } \\
\text { spermic }\end{array}$ \\
\hline Basic medium & & $\begin{array}{l}101 \\
132 *\end{array}$ & $\begin{array}{l}0(0) \\
0(0)\end{array}$ & $\begin{array}{l}0(0) \\
0(0)\end{array}$ & $\begin{array}{l}0 \\
0\end{array}$ & $\begin{array}{l}0 \\
0\end{array}$ \\
\hline +sodium lactate & $\begin{array}{l}10 \\
20 \\
20 \\
30 \\
40\end{array}$ & $\begin{array}{c}94 \\
103 \\
188^{*} \\
85 \\
91\end{array}$ & $\begin{aligned} 3(3 \cdot 2) \\
12(11 \cdot 7) \\
15(8 \cdot 0) \\
8(9 \cdot 4) \\
7(7 \cdot 7)\end{aligned}$ & $\begin{array}{r}3(3 \cdot 2) \\
10(9 \cdot 7) \\
10(5 \cdot 3) \\
7(8 \cdot 2) \\
5(5 \cdot 5)\end{array}$ & $\begin{array}{r}3 \\
10 \\
9 \\
7 \\
5\end{array}$ & $\begin{array}{l}0 \\
0 \\
1 \\
0 \\
0\end{array}$ \\
\hline $\begin{array}{l}\text { +sodium } \\
\text { oxaloacetate }\end{array}$ & $\begin{array}{l}0 \cdot 3 \\
0 \cdot 3 \\
3\end{array}$ & $\begin{array}{l}104 \\
101^{*} \\
115\end{array}$ & $\begin{array}{l}16(15 \cdot 4) \\
10(9 \cdot 9) \\
10(8 \cdot 7)\end{array}$ & $\begin{array}{l}9(8 \cdot 7) \\
6(5 \cdot 9) \\
5(4 \cdot 3)\end{array}$ & $\begin{array}{l}9 \\
6 \\
5\end{array}$ & $\begin{array}{l}0 \\
0 \\
0\end{array}$ \\
\hline $\begin{array}{l}+ \text { trisodium } \\
\text { phosphoenol- } \\
\text { pyruvate }\end{array}$ & $\begin{array}{r}3 \\
10 \\
10\end{array}$ & $\begin{array}{l}120 \\
129 \\
110^{*}\end{array}$ & $\begin{array}{l}19(15 \cdot 8) \\
28(21 \cdot 7) \\
10(9 \cdot 1)\end{array}$ & $\begin{array}{c}12(10 \cdot 0) \\
19(14 \cdot 7) \\
7(6 \cdot 4)\end{array}$ & $\begin{array}{r}12 \\
18 \\
7\end{array}$ & $\begin{array}{l}0 \\
1 \\
0\end{array}$ \\
\hline +sodium pyruvate & $\begin{array}{l}0.2 \\
0.5 \\
1 \\
1 \\
2 \\
3\end{array}$ & $\begin{array}{c}88 \\
97 \\
88 \\
170^{*} \\
94 \\
85\end{array}$ & $\begin{array}{c}4(4 \cdot 5) \\
11(11 \cdot 3) \\
22(25 \cdot 5) \\
27(15 \cdot 9) \\
12(12 \cdot 8) \\
7(8 \cdot 2)\end{array}$ & $\begin{array}{c}3(3.4) \\
10(10 \cdot 3) \\
20(22 \cdot 7) \\
22(12 \cdot 9) \\
11(11 \cdot 7) \\
7(8 \cdot 2)\end{array}$ & $\begin{array}{r}3 \\
10 \\
20 \\
22 \\
11 \\
7\end{array}$ & $\begin{array}{l}0 \\
0 \\
0 \\
0 \\
0 \\
0\end{array}$ \\
\hline
\end{tabular}

achieved when epididymal spermatozoa and newly ovulated mouse eggs were incubated in a basic medium which is a modified Krebs-Ringer bicarbonate solution containing glucose. A low proportion of mouse eggs were penetrated $(3.2$ to $25.5 \%)$ when various concentrations of a metabolic intermediate were added to the basic medium. The maximum penetration rate, however, was observed in concentrations of 20 mm-lactate, $11.7 \%$; 0.3 mm-oxaloacetate, $15.4 \%$; 10 mm-phosphoenolpyruvate, $21.7 \%$; and 1 mm-pyruvate, $25.5 \%$. 
Pyruvate appeared to be better than the other metabolic intermediates for induction of the acrosome reaction (Table 1) and for the fertilization of mouse eggs in vitro (Table 2).

Various concentrations ( 1 to $50 \mathrm{mg} / \mathrm{ml}$ ) of serum albumin of different species were added to the basic medium for fertilization of mouse eggs in vitro (Table 3 ). It appears that the addition of as little as $1 \mathrm{mg}$ serum albumin $/ \mathrm{ml}$ basic medium

Table 3. Effect of various concentrations of serum albumin from different species on fertilization of mouse eggs in vitro

\begin{tabular}{|c|c|c|c|c|c|c|}
\hline \multirow{2}{*}{$\begin{array}{l}\text { Source } \\
\text { of serum } \\
\text { albumin }\end{array}$} & \multirow{2}{*}{$\begin{array}{l}\text { Concentration of } \\
\text { serum albumin } \\
(\mathrm{mg} / \mathrm{ml}) \text { in } \\
\text { basic medium }\end{array}$} & \multirow{2}{*}{$\begin{array}{c}\text { No. of } \\
\text { eggs } \\
\text { examined }\end{array}$} & \multirow{2}{*}{$\begin{array}{c}\text { No. of } \\
\text { penetrated } \\
\text { eggs }(\%)\end{array}$} & \multicolumn{3}{|c|}{$\begin{array}{c}\text { No. of eggs } \\
\text { undergoing fertilization }\end{array}$} \\
\hline & & & & Total $(\%)$ & $\begin{array}{l}\text { Mono- } \\
\text { spermic }\end{array}$ & $\begin{array}{l}\text { Poly. } \\
\text { spermic }\end{array}$ \\
\hline Basic medium & & $\begin{array}{l}177 \\
251^{*}\end{array}$ & $\begin{array}{l}0(0) \\
0(0)\end{array}$ & $\begin{array}{l}0(0) \\
0(0)\end{array}$ & $\begin{array}{l}0 \\
0\end{array}$ & $\begin{array}{l}0 \\
0\end{array}$ \\
\hline Bovine & $\begin{array}{r}1 \\
4 \\
4 \\
10 \\
20 \\
20 \\
30 \\
40 \\
50\end{array}$ & $\begin{array}{l}146 \\
187 \\
163^{*} \\
147 \\
195 \\
145^{*} \\
151 \\
173 \\
183\end{array}$ & $\begin{array}{r}48(32 \cdot 9) \\
96(51 \cdot 3) \\
68(41 \cdot 7) \\
91(63 \cdot 3) \\
156(80 \cdot 0) \\
84(57 \cdot 9) \\
103(68 \cdot 2) \\
114(65 \cdot 9) \\
102(55 \cdot 7)\end{array}$ & $\begin{array}{r}37(25 \cdot 3) \\
85(45 \cdot 5) \\
57(35 \cdot 0) \\
81(55 \cdot 1) \\
141(72 \cdot 3) \\
76(51 \cdot 7) \\
88(58 \cdot 3) \\
102(59 \cdot 0) \\
87(47 \cdot 5)\end{array}$ & $\begin{array}{r}36 \\
82 \\
55 \\
79 \\
136 \\
74 \\
86 \\
99 \\
84\end{array}$ & $\begin{array}{l}1 \\
3 \\
2 \\
2 \\
5 \\
2 \\
2 \\
3 \\
3\end{array}$ \\
\hline Horse & $\begin{array}{r}1 \\
4 \\
4 \\
10 \\
20 \\
20 \\
30\end{array}$ & $\begin{array}{l}151 \\
180 \\
128^{*} \\
201 \\
180 \\
140^{*} \\
145\end{array}$ & $\begin{array}{r}64(42 \cdot 4) \\
111(61 \cdot 7) \\
51(39 \cdot 8) \\
154(76 \cdot 6) \\
124(68 \cdot 9) \\
77(55 \cdot 0) \\
69(47 \cdot 6)\end{array}$ & $\begin{array}{r}53(35 \cdot 1) \\
98(54 \cdot 4) \\
40(31 \cdot 3) \\
142(70 \cdot 6) \\
112(62 \cdot 2) \\
65(46 \cdot 4) \\
55(37 \cdot 9)\end{array}$ & $\begin{array}{r}52 \\
93 \\
39 \\
137 \\
112 \\
63 \\
54\end{array}$ & $\begin{array}{l}1 \\
5 \\
1 \\
5 \\
0 \\
2 \\
1\end{array}$ \\
\hline Rabbit & $\begin{array}{r}1 \\
4 \\
4 \\
10 \\
20 \\
20 \\
30\end{array}$ & $\begin{array}{l}149 \\
126 \\
131^{*} \\
147 \\
164 \\
144^{*} \\
146\end{array}$ & $\begin{array}{r}69(46 \cdot 3) \\
72(57 \cdot 1) \\
69(52 \cdot 7) \\
115(78 \cdot 2) \\
141(86 \cdot 0) \\
90(62 \cdot 5) \\
100(68 \cdot 5)\end{array}$ & $\begin{array}{r}56(37 \cdot 6) \\
61(48 \cdot 4) \\
53(40 \cdot 5) \\
106(72 \cdot 1) \\
134(81 \cdot 7) \\
78(54 \cdot 2) \\
89(61 \cdot 0)\end{array}$ & $\begin{array}{r}56 \\
60 \\
52 \\
100 \\
130 \\
75 \\
88\end{array}$ & $\begin{array}{l}0 \\
1 \\
1 \\
6 \\
4 \\
3 \\
1\end{array}$ \\
\hline Human & $\begin{array}{r}1 \\
4 \\
4 \\
10 \\
20 \\
20 \\
30\end{array}$ & $\begin{array}{l}139 \\
151 \\
110^{*} \\
140 \\
155 \\
134^{*} \\
142\end{array}$ & $\begin{array}{c}6(4 \cdot 3) \\
51(33 \cdot 8) \\
32(29 \cdot 1) \\
85(60 \cdot 7) \\
86(55 \cdot 5) \\
59(44 \cdot 0) \\
43(30 \cdot 3)\end{array}$ & $\begin{array}{c}6(4 \cdot 3) \\
42(27 \cdot 8) \\
20(18 \cdot 2) \\
74(52 \cdot 9) \\
77(49 \cdot 7) \\
46(34 \cdot 3) \\
30(21 \cdot 1)\end{array}$ & $\begin{array}{r}6 \\
42 \\
20 \\
73 \\
74 \\
44 \\
29\end{array}$ & $\begin{array}{l}0 \\
0 \\
0 \\
1 \\
3 \\
2 \\
1\end{array}$ \\
\hline
\end{tabular}

Eggs and spermatozoa were incubated for 5 to $7 \mathrm{hr}$.

* Cumulus mass was washed three times.

can induce mouse spermatozoa to fertilize mouse eggs in vitro $37.6 \%$ in rabbit serum albumin) but the highest penetration rates, $86.0 \%, 80.0 \%, 76.6 \%$ and $60.7 \%$, were obtained in concentrations of $20 \mathrm{mg}$ rabbit serum albumin $/ \mathrm{ml}$, $20 \mathrm{mg}$ bovine serum albumin/ml, $10 \mathrm{mg}$ horse serum albumin $/ \mathrm{ml}$ and $10 \mathrm{mg}$ human serum albumin $/ \mathrm{ml}$, respectively. Although human serum albumin appeared to be less efficient for the fertilization of mouse eggs in vitro (4.3 to $60.7 \%$ penetrated eggs) than the serum albumin of other species $(32.9$ to $86 \%$ 
Fertilization of mouse eggs in vitro

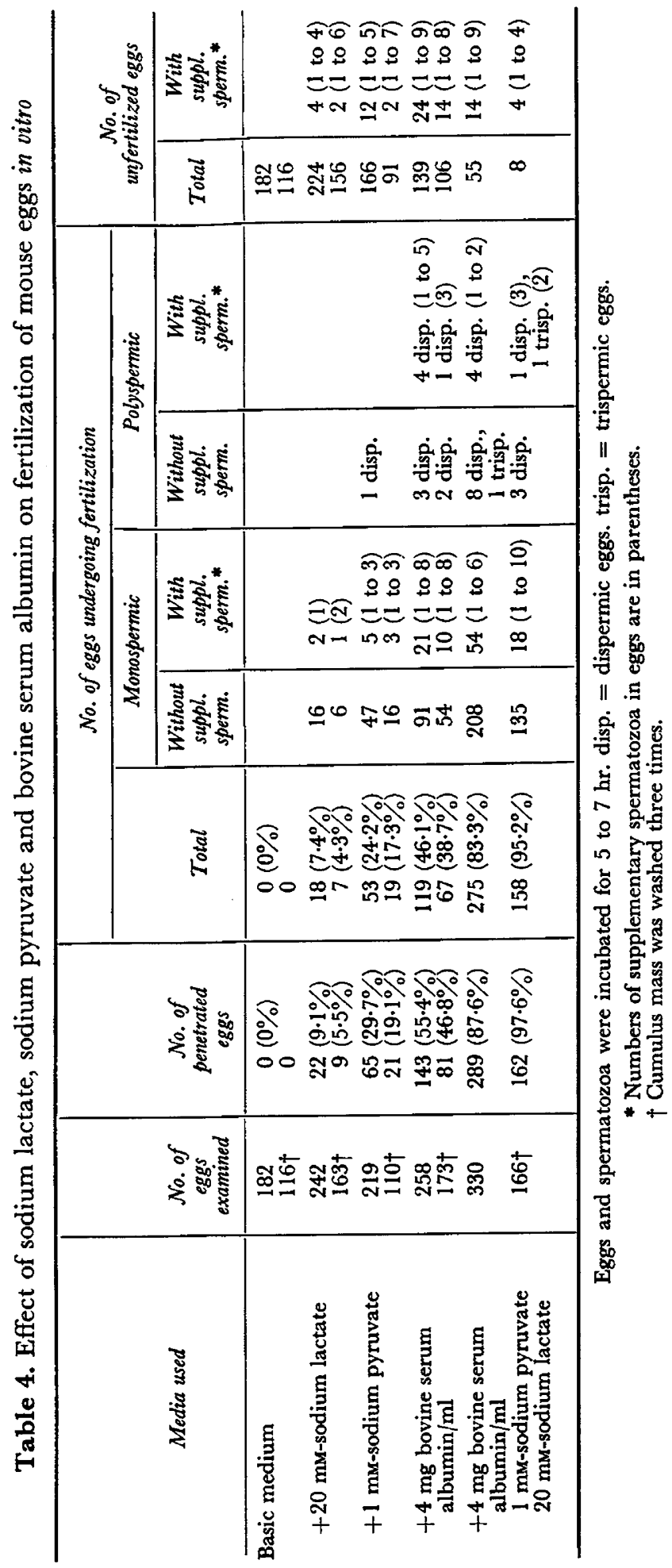


penetrated eggs), there was no striking difference between the effectiveness of bovine, horse and rabbit serum albumin.

Fertilization of mouse eggs in vitro was further studied by the addition of lactate, pyruvate or serum albumin alone or by the addition of these three substances together to the basic medium. The percentages of penetrated eggs when epididymal spermatozoa and eggs were incubated in the basic medium alone, basic medium containing lactate, pyruvate or bovine serum albumin alone, or basic medium containing these three substances were $0,9 \cdot 1,29 \cdot 7$, 55.4 and $87.6 \%$, respectively (Table 4 ). It seems that the addition of these three substances together in a modified Krebs-Ringer bicarbonate solution gives the best results for fertilization of mouse eggs in vitro. The numbers of polyspermic eggs and eggs with supplementary spermatozoa were relatively high when serum albumin alone or lactate, pyruvate and serum albumin were added to the basic medium (Table 4). Since the proportion of penetrated eggs was also high $(55.4$ to $87.6 \%$ ) when spermatozoa and eggs were incubated in these two media, it seems that serum albumin alone, or with lactate and pyruvate, can efficiently induce sperm capacitation. The occurrence of supplementary spermatozoa in the unfertilized eggs (Table 4) may indicate a certain physiological deterioration of the vitellus under such experimental conditions. Even when a large number of spermatozoa were capacitated and able to penetrate through the zona pellucida, the vitellus of the egg failed to accept the spermatozoa.

Effects of components present in the oviducal fuid and mucus clots on fertilization in vitro

In this study, the newly-ovulated eggs in the cumulus clot were recovered from the oviduct, so that contamination of oviducal fluid with the egg clot was expected. In order to examine whether the oviducal fluid plays any rôle in fertilization in vitro, the cumulus egg clots were washed three times before insemination in a number of tests. A comparison of the results obtained from unwashed and washed egg clots (with and without asterisks in Tables 2, 3 and 4) showed that, except in the case where basic medium containing bovine serum albumin, pyruvate and lactate was used (last row, Table 4), the percentages of penetrated eggs were always higher in the unwashed egg samples (average, $46.2 \%$; range, 9.1 to $86 \%$ ) than in the washed egg samples (average, $33.3 \%$; range, 5.5 to $62.5 \%$ ). When bovine serum albumin, pyruvate and lactate were added to the basic medium, the proportion of penetrated eggs was $87.6 \%$ in the unwashed eggs and $97.6 \%$ in the washed eggs (Table 4). These components, which can be washed away, may be similar to the combination of serum albumin, pyruvate and lactate. This is shown by the fact that, in the absence of two of these three substances in the culture medium, the penetration rate was always higher in the unwashed egg samples (46.2\%) than in the washed egg samples $(33.3 \%)$. In the presence of these three substances, the penetration rate was the same or slightly higher in the washed egg samples $(97.6 \%)$ than in the unwashed egg samples $(87.6 \%$, Tables 2,3 and 4$)$.

Time required for the capacitation of mouse spermatozoa in vitro

Epididymal spermatozoa and newly ovulated eggs were incubated in the 
basic medium containing serum albumin of different species. The preparations were examined at various times after incubation in order to determine the time of sperm penetration in various media. Results presented in Table 5 show that there was no significant difference between the albumin from different species. In each case, sperm penetration started $2 \mathrm{hr}$ after incubation $(1.7$ to $5.2 \%$ penetrated eggs) and the proportion of penetrated eggs increased markedly from $3 \mathrm{hr}(10$ to $33 \%)$ to $5 \mathrm{hr}(65$ to $82 \%)$ but no further increase had occurred $6 \mathrm{hr}$ after incubation (64 to $79 \%$ ). It thus appears that $2 \mathrm{hr}$ were required for

Table 5. Time required for capacitation of mouse spermatozoa in vitro in the basic medium containing serum albumin from various species

\begin{tabular}{l|c|c|c|c}
\hline $\begin{array}{c}\text { Serum } \\
\text { albumin } \\
(10 \mathrm{mg} / \mathrm{ml})\end{array}$ & $\begin{array}{c}\text { Incubation } \\
\text { time (hr) }\end{array}$ & $\begin{array}{c}\text { No. of eggs } \\
\text { examined }\end{array}$ & $\begin{array}{c}\text { No. of } \\
\text { penetrated eggs } \\
(\%)\end{array}$ & $\begin{array}{c}\text { No. of eggs } \\
\text { undergoing } \\
\text { fertilization }(\%)\end{array}$ \\
\hline Bovine & 1 & 113 & $0(0)$ & $0(0)$ \\
& 2 & 115 & $2(1 \cdot 7)$ & $0(0)$ \\
& 3 & 114 & $38(33 \cdot 3)$ & $25(21 \cdot 9)$ \\
& 4 & 86 & $52(60 \cdot 5)$ & $40(46 \cdot 5)$ \\
& 6 & 113 & $87(77 \cdot 0)$ & $75(66 \cdot 4)$ \\
& 1 & 65 & $63(66 \cdot 3)$ & $55(57 \cdot 9)$ \\
\hline Horse & 121 & $0(0)$ & $0(0)$ \\
& 3 & 135 & $7(5 \cdot 2)$ & $0(0)$ \\
& 4 & 109 & $26(23 \cdot 9)$ & $19(17 \cdot 4)$ \\
& 5 & 120 & $66(47 \cdot 5)$ & $56(40 \cdot 3)$ \\
& 6 & 129 & $81(67 \cdot 5)$ & $69(57 \cdot 5)$ \\
& 1 & $90(69 \cdot 7)$ & $81(62 \cdot 8)$ \\
\hline Rabbit & 103 & $0(0)$ & $0(0)$ \\
& 2 & 120 & $5(4 \cdot 2)$ & $0(0)$ \\
& 3 & 159 & $35(22 \cdot 0)$ & $23(14 \cdot 5)$ \\
& 4 & 122 & $69(56 \cdot 6)$ & $55(45 \cdot 1)$ \\
& 5 & 144 & $118(81 \cdot 9)$ & $107(74 \cdot 3)$ \\
& 6 & 114 & $90(78 \cdot 9)$ & $80(70 \cdot 2)$ \\
\hline Human & 1 & 96 & $0(0)$ & $0(0)$ \\
& 2 & 118 & $3(2 \cdot 5)$ & $0(0)$ \\
& 3 & 154 & $16(10 \cdot 4)$ & $9(5 \cdot 8)$ \\
& 4 & 141 & $48(34 \cdot 0)$ & $39(27 \cdot 7)$ \\
& 5 & 97 & $63(64 \cdot 9)$ & $54(55 \cdot 7)$ \\
& 6 & 131 & $84(64 \cdot 1)$ & $74(56 \cdot 5)$ \\
\hline & & & & \\
\hline
\end{tabular}

the capacitation of mouse spermatozoa in media containing serum albumin from various species. When the basic medium containing lactate, pyruvate and bovine serum albumin was tested (Table 6), sperm penetration occurred $1 \mathrm{hr}$ after incubation. The percentage of penetrated eggs increased markedly from $2 \mathrm{hr}(49 \%)$ to $4 \mathrm{hr}(88 \%)$, but no further increase occurred 5 to $6 \mathrm{hr}$ after incubation ( 79 to $85 \%$ ). The number of polyspermic eggs, the number of eggs with supplementary spermatozoa, and the number of supplementary spermatozoa in each egg did not noticeably increase over a 6-hr period of incubation.

\section{DISCUSSION}

In the study of acrosome reaction, epididymal spermatozoa were incubated 


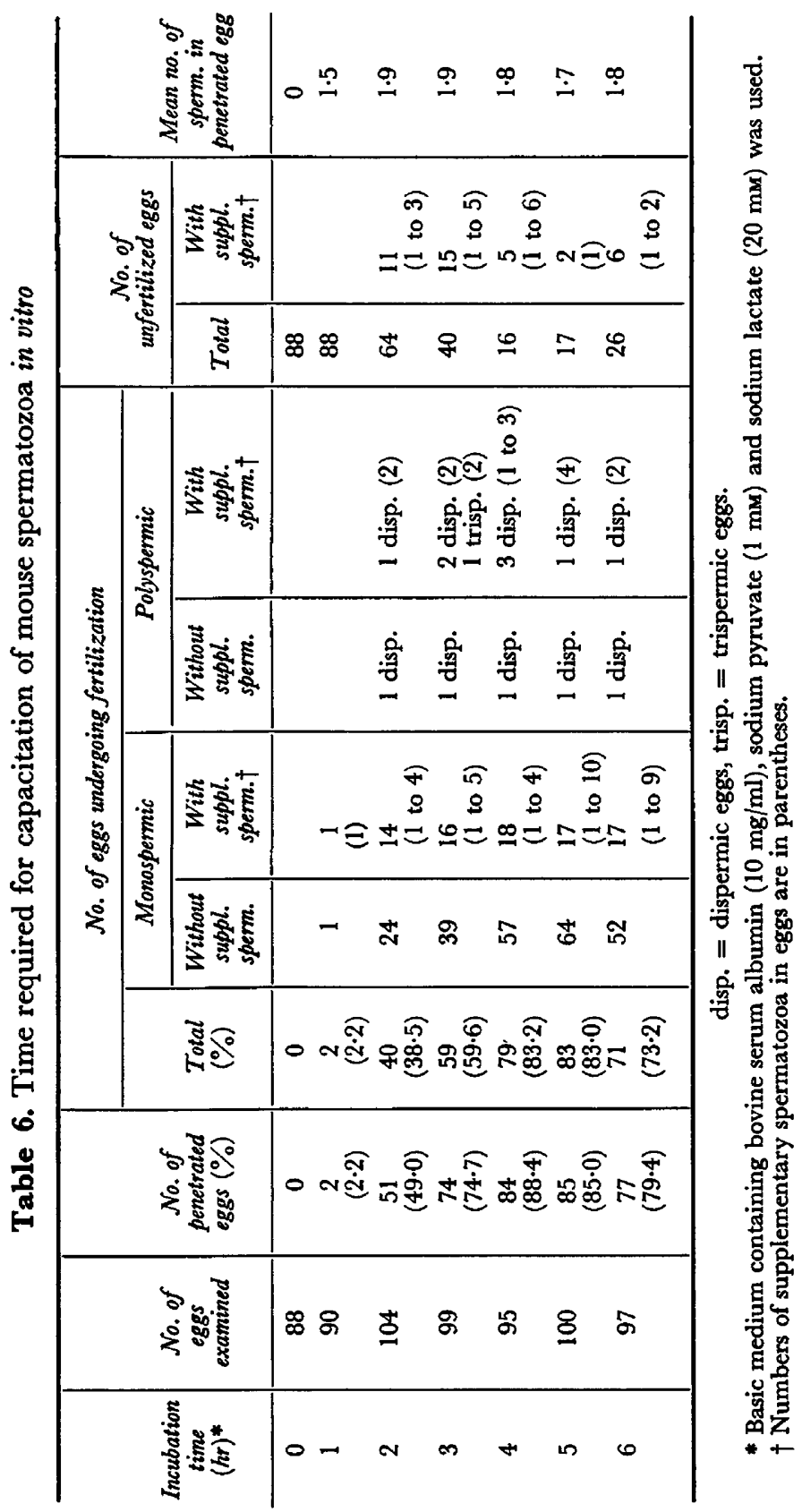


in various media in the presence of cumulus egg clots (Table 1) since it was thought that loss of the acrosome might be influenced by their presence. When epididymal spermatozoa were incubated for $5 \mathrm{hr}$ in the absence of cumulus egg clots, however, the acrosome reaction was still observed (Table 1). On the basis of studies with the electron microscope, Bedford (1970) has stated that the acrosome can be discharged from the sperm head in the course of either a 'false' (degenerative) or a 'true' (physiological) acrosome reaction. When suspended in various media before incubation, no more than 6 to $9 \%$ immotile spermatozoa without an acrosome and only 0 to $3 \%$ motile spermatozoa without an acrosome have been observed by phase-contrast microscopy. This shows that the occurrence of a false or degenerative acrosome reaction in epididymal spermatozoa is very rare, a finding which is in agreement with that following an electron microscope study by Franklin, Barros \& Fussell (1970) on hamster spermatozoa.

Elevation and detachment of the acrosome has been considered to constitute capacitation (Austin \& Bishop, 1958), but there are different interpretations of acrosome reaction in relation to capacitation (cf. Bedford, 1970; Zamboni, 1971; Austin, Bavister \& Edwards, 1972; Chang \& Hunter, 1972; Yanagimachi \& Noda, 1972). In the present study, we have observed, in general, a fairly close relationship between the occurrence of the acrosome reaction and sperm penetration. Since the acrosome reaction is ascertained by morphological observation of spermatozoa while sperm capacitation is judged by the ability to penetrate eggs, it is difficult to establish a definite correlation between acrosome reaction and capacitation. The former may precede but not entirely constitute the latter.

By comparison of the penetration rates (Table 4) when sodium lactate $(9.1 \%)$, sodium pyruvate $(29.7 \%)$, bovine serum albumin $(55.4 \%)$, or all these three substances $(87.6 \%$ ) were added to the basic medium, it is quite clear that the presence of these three substances is of importance for the capacitation of spermatozoa and the fertilization of mouse eggs in vitro. Considering the fact that a high proportion of eggs can be penetrated in the basic medium containing serum albumin alone $(60.7$ to $86.0 \%$, Table 3$)$, it may be concluded that serum albumin is the major component for the capacitation of spermatozoa and sodium lactate and sodium pyruvate only facilitate the process. That the time required for capacitation was $1 \mathrm{hr}$ in the presence of serum albumin plus sodium lactate and sodium pyruvate, but $2 \mathrm{hr}$ in the presence of serum albumin only (Tables 5 and 6 ), also supports this statement.

In the first study of fertilization of hamster eggs in vitro, it was reported that the proportion of fertilized eggs was lower and the time required to fertilize eggs was longer when epididymal spermatozoa were used than when spermatozoa recovered from the uterus were used (Yanagimachi \& Chang, 1963, 1964). Later, it was reported that the presence of follicular fluid or fractions of serum in the medium could induce the acrosome reaction of epididymal hamster spermatozoa and thus increase the rate of fertilization (Barros \& Austin, 1967; Yanagimachi, 1969a, b, 1970). The studies by Bavister (1969) in the hamster, by Toyoda et al. (1971) in the mouse, and the present study when chemically defined media were used, have made it clear that neither 
fluids from the female tract nor any animal fluid such as follicular fluid or blood serum is essential for the achievement of capacitation in vitro.

The proportions of mouse eggs which could be fertilized in vitro were from 10.4 to $40.9 \%$ (Whittingham, 1968), from 26.2 to $26.8 \%$ (Mukherjee $\&$ Cohen, 1970) and from 46.3 to $90.1 \%$ (Cross \& Brinster, 1970) by using capacitated spermatozoa recovered from the uterus. With epididymal spermatozoa, the proportion of penetrated eggs ranged from 33.3 to $86 \%$ in the presence of heated bovine follicular fluid (Iwamatsu \& Chang, 1970, 1971). Insemination with epididymal spermatozoa in chemically defined media resulted in the fertilization of $92.7 \%$ (Toyoda et al., 1971) and $64 \%$ of mouse eggs (Miyamoto \& Chang, 1972). From this account, it seems that so far as the fertilization rate is concerned, there is little difference between the spermatozoa recovered from the uterus and those obtained from the epididymis. Use of the proper medium, procedures and technique are of great importance for the achievement of fertilization in vitro of mouse eggs.

\section{ACKNOWLEDGMENTS}

This work was supported by grants (GM 14370, HD 03472) from the USPHS and a grant from the Ford Foundation. M.C.C. is a recipient of a Research Career Award of the NICHD (K6-HD 18,334).

\section{REFERENCES}

Austin, C. R., Bavister, B. D. \& Edwards, R. G. (1972) Components of capacitation. In: Regulation of Mammalian Reproduction. Eds. S. J. Segal, R. Crozier, P. Corfman and P. Condliffe. Charles C. Thomas, Springfield, Illinois.

Austin, C. R. \& Bishop, M. W. H. (1958) Role of the rodent acrosome and perforatorium in fertilization. Proc. R. Soc. B, 149, 241.

Barros, C. \& Austin, C. R. (1967) In vitro fertilization and the sperm acrosome reaction in the hamster. F. $\exp$. Zool. 166, 317.

Barros, G. \& Garavagno, A. (1970) Capacitation of hamster spermatozoa with blood sera. F. Reprod. Fert. 22, 381.

Bavister, B. D. (1969) Environmental factors important for in vitro fertilization in the hamster. $\mathcal{F}$. Reprod. Fert. 18, 544.

Bedford, J. M. (1970) Sperm capacitation and fertilization in mammals. Biol. Reprod. Suppl. 2, 128.

BRINSTER, R. L. (1965) Studies on the development of mouse embryos in vitro. IV. Interaction of energy sources. F. Reprod. Fert. 10, 227.

Caravaglios, R. \& Cilottr, R. (1957) A study of the proteins in follicular fluid of the cow. F. Endocr. $15,273$.

Chang, M. C. (1947) The effects of serum on spermatozoa. F. gen. Physiol. 30, 321.

Ghang, M. G. \& Hunter, R. H. F. (1972) Capacitation of mammalian sperm: biological and experimental aspects. In: Handbook of Physiology, Section of Endocrinology. Eds. E. B. Astwood and R. O. Greep. American Physiological Society, Washington, D.C.

Cross, P. G. \& Brinster, R. L. (1970) In vitro development of mouse oocytes. Biol. Reprod. 3, 298.

FrankLIN, L. E., Barros, C. \& Fussell, E. N. (1970) The acrosomal region and the acrosome reaction in sperm of the golden hamster. Biol. Reprod. 3, 180.

Iwamatsu, T. \& Chang, M. C. (1969) In vitro fertilization of mouse eggs in the presence of bovine follicular fluid. Nature, Lond. 224, 919.

Iwamatsu, T. \& Ghang, M. G. (1970) Further investigation of capacitation of sperm and fertilization of mouse eggs in vitro. F. exp. Zool. 175, 271.

Iwamatsu, T. \& Chang, M. G. (1971) Factors involved in the fertilization of mouse eggs in vitro. 7. Reprod. Fert. 26, 197.

Lutwak-ManN, C. (1954) Note on the chemical composition of bovine follicular fluid. F. agric. Sci., Camb. 44, 477 . 
Mryamoto, H. \& Ghang, M. C. (1972) Development of mouse eggs fertilized in vitro by epididymal spermatozoa. J. Reprod. Fert. 30, 135.

MukherJee, A. B. \& Cohen, M. M. (1970) Development of normal mice by in vitro fertilization. Nature, Lond. 228, 472.

Toyoda, Y., Yokoyama, M. \& Hosi, T. (1971) Studies on the fertilization of mouse eggs in vitro. I. In vitro fertilization of eggs by fresh epididymal sperm. Jap. F. Anim. Reprod. 16, 147.

Whittingham, D. G. (1968) Fertilization of mouse eggs in vitro. Nature, Lond. $220,592$.

YANAGIMACHI, R. (1969a) In vitro acrosome reaction and capacitation of golden hamster spermatozoa by bovine follicular fluid and its fractions. F. exp. Zool. 170, 269.

YANAGIMACHI, R. (1969b) In vitro capacitation of hamster spermatozoa by follicular fluid. f. Reprod. Fert. 18, 275.

YANAGIMACHI, R. (1970) In vitro capacitation of golden hamster spermatozoa by homologous and heterologous blood sera. Biol. Reprod. 3, 147.

Yanagimaghi, R. \& Chang, M. C. (1963) Fertilization of hamster eggs in vitro. Nature, Lond. 200, 281.

Yanagimachi, R. \& Chang, M. C. (1964) In vitro fertilization of golden hamster ova. F. exp. Zool. 156. 361.

Yanagimachi, R. \& NodA, Y. D. (1972) Acrosome loss in fertilizing mammalian spermatozoa: a rebuttal of criticism. F. Ultrastruct. Res. 39, 217.

Zamboni, L. (1971) Acrosome loss in fertilizing mammalian spermatozoa: a clarification. $\mathbf{f}$. Ultrastruct. Res. 34, 401. 